\title{
Park and ride city terminal, Antapani Bandung
}

\author{
Inggrid Julianti Dewi ${ }^{\mathrm{a}^{*}}$, Usep Surahman ${ }^{\mathrm{a}}$ \\ Departement of Architectural Engineering Education, Universtas Pendidikan Indonesia, Bandung 41054, Indonesia \\ *Corresponding author. Tel.: +62-818-0228-0066; Fax: - \\ E-mail address:inggridjuliantidewi@gmail.com
}

\begin{abstract}
Bandung as a growing city has transportation problem as other big cities have in Indonesia. About 3.55 million person/day (7.2\% move in the morning peak hour) is moved within the city to make more crowded. Thus, a good urban planning is necessary. An urban planning cannot be separated from mass transportation system. City terminal is one of transportation infrastructures that serves mass transport on a local/city scale. City terminal is built by nodes of people activities such as schools, markets, residential areas, offices, etc. The principle of planning on land transport network system is to connect the system of city activities optimally according to the Masterplan of Transportation network. The purpose of this paper is to design a city terminal that can accommodate people movements and activities as well as can decrease the rate of personal vehicles uses by persuading people to use public transportation. City Terminal which was developed in the first nodes of people movements aims to break and cope up the density with functional approaches such as park and ride system. This paper explains how a city terminal could decrease a number of vehicle's density by using park and ride concept in a residential area where is a start and end point of the system transport network. Park \& ride is the type of terminal where the passengers' personal vehicles can park and continue their journey by using public transportation instead. The paper ends by designing a park and ride city terminal located in Antapani, Bandung.
\end{abstract}

Keywords: terminal; transportation; park and ride

\section{Introduction}

A Terminal is a node in the land transport network that serves as a public service. A Terminal in the city was built by node of people activities such as schools, residential areas, markets, offices, and so on. As a study case, the data movement of people in Bandung, that was collected from Bandung Masterplan o Trasnportation, is increasing in every year, and most of them moves to the downtown as the center of human activity in everyday. 
Antapani is a residential area. In the period of 12 years, Antapani is growing very rapidly so it becomes a fairly dense residential area. Most of the movement of people in this area is moving towards the west (to the downtown). However, this area does not have enough public transportation to get there. Even to reach the nearest node, there is no public transportation that can move people to get there. This existing region has only two route public

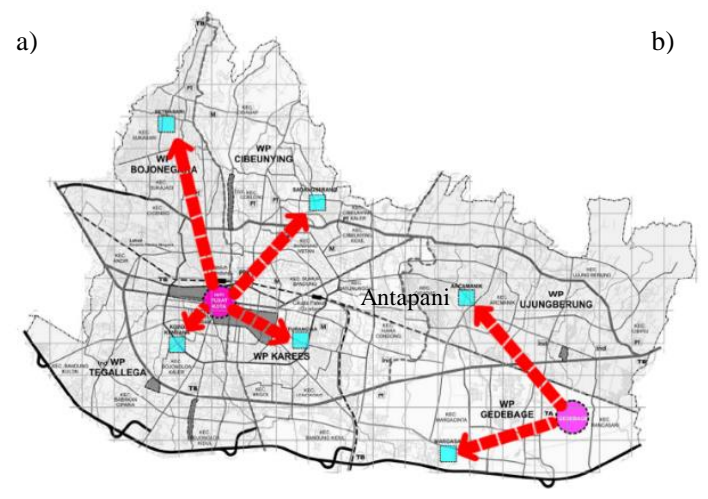

b)

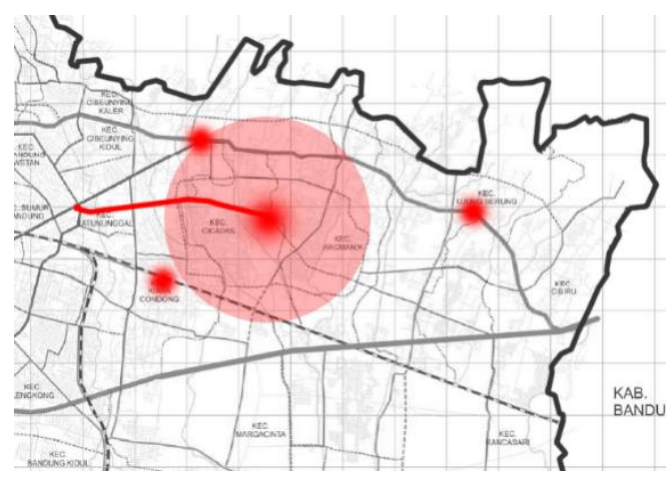

Fig. 1. a) Bandung with two City Service Center; b) Antapani with the nearest node

transportation, there are angkot number 31 routes Antapani - Ciroyom, and School Bus routes Antapani - Ledeng. This caused people to use private vehicles than public transportation. The more that people use private vehicles, more traffic congestion get increase, which caused a huge of wasting time, especially, jammed would makes stress and unhappiness.

This problem can be solved by two solutions, first is adding the modes of public transportation that entering the residential areas, and the second is designing Park and Ride System in the terminal of that area.

However, after the issuance of Bandung Masterplan of Transportation, the first solution has been answered by adding a number of public transportation to solves people's movements such as BRT (Bus Rapid Trans) Trans Metro Bandung, School Bus and Monorail. So now, Antapani would has four kinds of transportation that passed almost of its whole areas. Therefore, the design problems can be identified as follows:

1) How to design a terminal that can engage people switch over from use their own vehicle to using public transport?

2) How to design a terminal that can bear the movement of private vehicles in that surrounding area?

3) How to design a good circulation in the terminal that was integrated by various types public transportation?

4) How to optimize the concept of park and ride on the design of this terminal?

\section{Theory and Methods}

A Terminal is one of land transportations that has function to pick up and drop off cargo, the movement of and the dispatch of the transportations. According to (KEPMENHUB No. 31 Th. 1995, 1995), Terminal is a transportation building that has function to pick up and drop off cargo, the movement of and the dispatch of the transportations. Terminal can be categorized as Type A, Type B and Type C. The task of Type B station is to provide public transportation for rural and or in the city.

City Terminal accommodates its activity for public transportation such as bus, angkot, taxi, monorail and etc. The type of the transportations is to adapt necessary section and the type of different transportation from each location. That makes the terminal is one of station typology type $\mathrm{C}$ and it is also seconder station that is included in the substation.

A special occasion that the passenger can do in the station with the function of kiss and ride also park and ride are:

a. Park its car

b. Buy a ticket 

c. Waiting
d. Ride the transportation and start the trip
e. To end the trip with the public transportation and then use the parked vehicle to go home.

\subsection{Methods}

\subsubsection{Design Approanchment}

First, To design a terminal with a good circulation, has no cross circulation between vehicles and people, the system approachment is a phase of troubleshooting a design problem that was in every steps has some alternative solution that can be considered to applied. So this system approachment is applied in people circulation where people (visitors) would be forced through the way that direct them to take or off from bus or monorail or another public transportation else. For this terminal case, transportation circulation is a major, so people have to be yeild. Therefore, the application o system approachment of people circulation is also completed with something "persuade" which is designed bye behavioral approachment.

Second, this behavior problem has been happen in every bus station in Bandung, that people often take or off the bus arbitrarily, it means not in it place.Thus, behavioral approachment is applied in manage people to use every space as it should be. For example, make the interchange space closer to main building so people should enter the building to take a bus, no more reason such as too lazy to enter the building because it takes a long way to go.

\subsubsection{Urban Exploration}

1) Rute analysis

The development of the transportation network plan is related to the road and railway network system. The principle of the transportation network system plan is connecting the system of city activity optimally, whether it is a regional context or internal city context (service centre and service subcenter city).

The existing of Antapani Terminal was the last node of public transportation. Therefore, people in this area Jalan Terusan Antapani is passed by monorail corridor 2 with the monorail station, which is across to Antapani Terminal. That condition makes the task of the terminal increase and became a transit place for buses to monorail, or the other way.

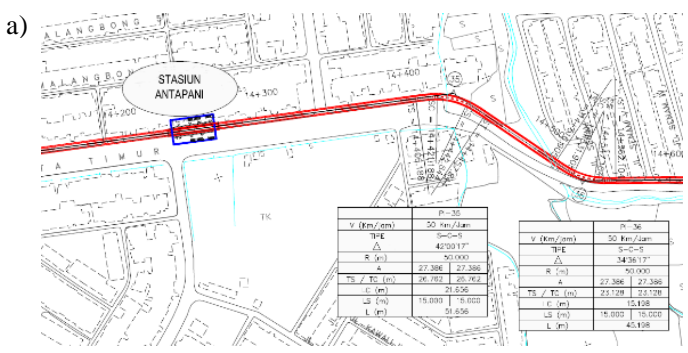

b)

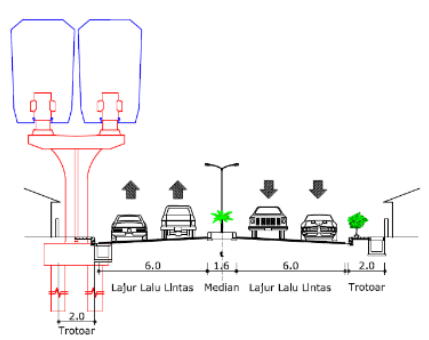

Fig. 2 a) Monorail plan in Antapani; b) Section of Jalan Terusan Jakarta

1. Bus Rapid Transit (BRT) Trans Metro Bandung

According to Masterplan Transportasi Kota Bandung 2013, there is two corridors of Bus Rapid Transit (BRT) or people also called it Trans Metro Bandung, which is through Terusan Jakarta Street, namely: Antapani - Leuwi Panjang. There is one extra corridor in the BRT Bandung City network, namely AntapaniStasiun Hall corridor. The total corridor BRT which is through Antapani region is two sections, with Antapani station as a main dispatch and last stoppage.

2. Angkutan Kota (Angkot)

There are 38 sections for angkot in Bandung, but the service area is not coping all of the region in Bandung, so it makes a blank spot in several regions. That also makes the citizen use their own vehicle to go to their destination, and moved from angkot because they feel unused. Antapani is only through by one angkot 
section, namely Antapani-Ciroyom. This section stops at Antapani Terminal, so it makes a blank spot, and as the consequence for that blank spot is the region around Antapani and Arcamanik is not passed by angkot.

3. School Bus

The operational hour of school bus in Bandung is only from 05.00-07.30, 11.00-14.00, and 16.00-18.30. Beside that operational hour, the school bus comes back to the Pool, it makes the station does not provide a school bus park area. A bus school section, which is through Antapani region, is a school bus in AntapaniLedeng Corridor, with their own operational hour. The total of school bus is 10 school buses.

2) Traffic density analysis

Table 1. Survey of Vehicle User on Bandung Masterplan of Transportation

\begin{tabular}{lllll}
\hline Observation Point & Motorcycle & Light Vehicle & Height Vehicle & Total \\
\hline Jl. A. Yani (from Jl. Ibrahim Ajie's junction to & 702 & 1628 & 21 & 2354 \\
Jl. P.H.H. Mustoa's junction) & & & & 1742 \\
Jl. Ibrahim Ajie & 165 & 1416 & $\mathbf{9 2 0}$ & $\mathbf{1 1 4 0}$ \\
Jl. Terusan Jakarta & $\mathbf{2 2 0}$ & 3148 & 541 & 4471 \\
Jl. A.H. Nasution 1 (Cicaheum) & 782 & & $\mathbf{0}$ \\
\hline
\end{tabular}

According to Masterplan Transportasi Kota Bandung 2013 above, it shows that the amount of vehicle in around Jalan Terusan Jakarta in peak hour 7.00-9.00 and 17.00-19.00. As it is recorded that the total of motorcycle in peak hour is 220 motorcycles, light vehicle is 920 , height vehicle 0 , with the total of all is 1140 vehicles. According to Indonesia Highway Capacity Manual Bina Marga 1997 edition, the vehicle itself is categorised in several types

1. Light Vehicle, is a four-tire vehicle, with two levers in level 2,0 - 3,0 m (includes passenger vehicle, micro bus, pick up and mini truck)

2. Heavy Vehicle, is the vehicle in level more than $3,50 \mathrm{~m}$, usually more than four tires (includes bus, truck two ases, truck three ases and combination truck).

3. Motor Cycle is two-tire or three-tire vehicle (includes motorcycle)

4. Unmotorized is a vehicle that does not have a machine (includes bicycle, delman, and pedicab)

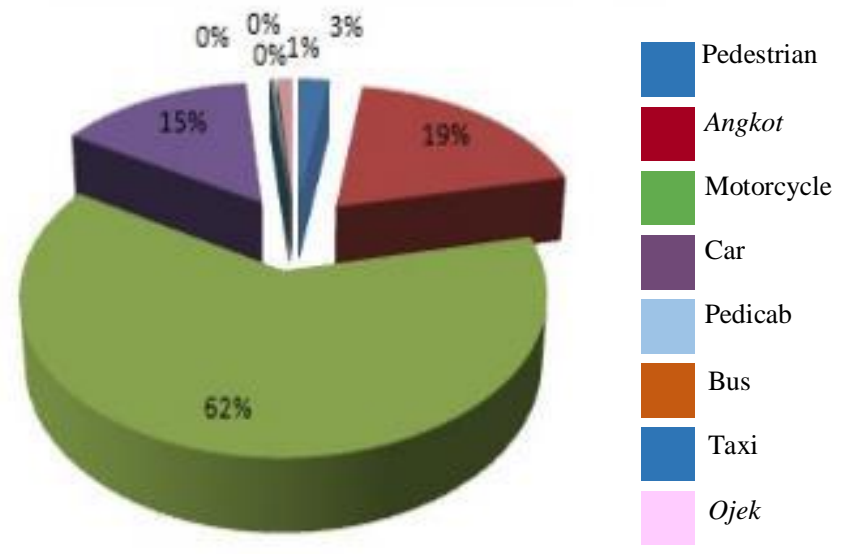

Fig. 3 Transportation User Percentation 
In the use of modes of transport in the city of Bandung, light vehicles including cars, public transportation, and taxis.

$\begin{array}{lll}\text { Angkot } & =19 \% \\ \text { Car } & & =15 \% \\ \text { Taxi } & =0 \% \\ \text { Total } & =34 \% \\ \text { Number of car users } & =44 \% \text { of total light vehicle users }\end{array}$

Table 2. Vehicle user percentation

\begin{tabular}{llll}
\hline Observation Point & Motorcycle & Light Vehicle & Height Vehicle \\
\hline Jl. A. Yani (from Jl. Ibrahim Ajie's junction to & $34.9 \%$ & $59.9 \%$ & $5.2 \%$ \\
Jl. P.H.H. Mustoa's junction) & & & \\
Jl. Ibrahim Ajie & $54.5 \%$ & $45.5 \%$ & $0.0 \%$ \\
Jl. Terusan Jakarta & $52.3 \%$ & $42.1 \%$ & $5.6 \%$ \\
Jl. A.H. Nasution 1 (Cicaheum) & $77.3 \%$ & $21.2 \%$ & $1.6 \%$ \\
Average & $\mathbf{5 6 . 4 2 \%}$ & $\mathbf{3 8 . 5 3 \%}$ & $\mathbf{3 . 0 4 \%}$ \\
\hline
\end{tabular}

Number of car users $\quad=44 \%$ of total light vehicle users in one day

$$
\begin{aligned}
& =44 \% \times 38.53 \% \\
& =17 \%
\end{aligned}
$$

This terminal will cut the traffic density, especially at peak hour.

The number of cars at peak hour $\quad=17 \%$ of the total vehicles in peak hour

$$
\begin{aligned}
& =17 \% \text { x } 1140 \\
& =\mathbf{1 0 2} \text { cars }
\end{aligned}
$$

There is no special calculation for parking capacity at both terminal types A, B, and C. Therefore, it would be calculate by approaching the calculation of parking capacity of the shopping center which has parking lots with long duration.

\subsubsection{Site Exploration}

1) Site analysis

Antapani Terminal is located at Jalan Terusan Jakarta, Bandung, precisely at the intersection between Jalan Terusan Jakarta and Jalan Jalan Cibatu with an area of $3.178 \mathrm{~m}^{2}$ wide. Antapani Terminal is an existing terminal, which was redesigned with additional land of $10.672 \mathrm{~m}^{2}$ to $13.820 \mathrm{~m}^{2}$ breadth become.

a)

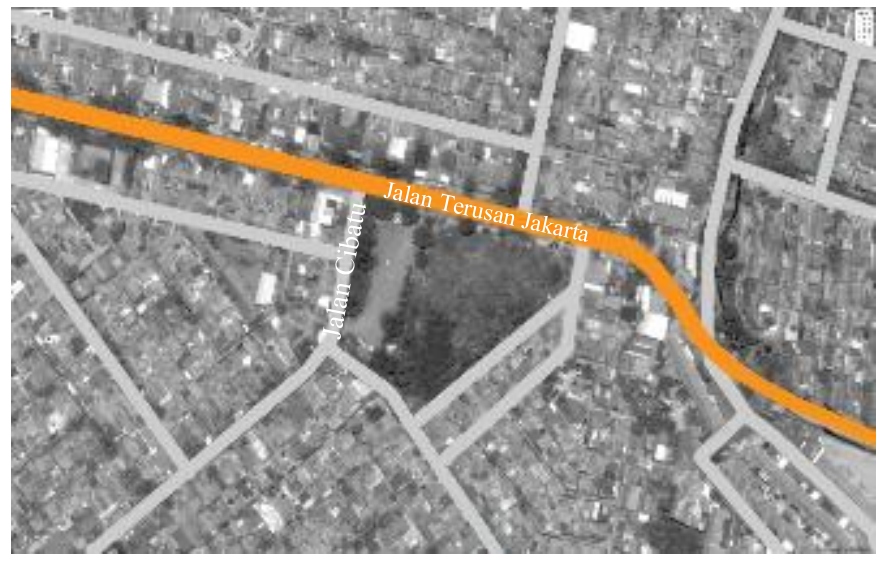

b)

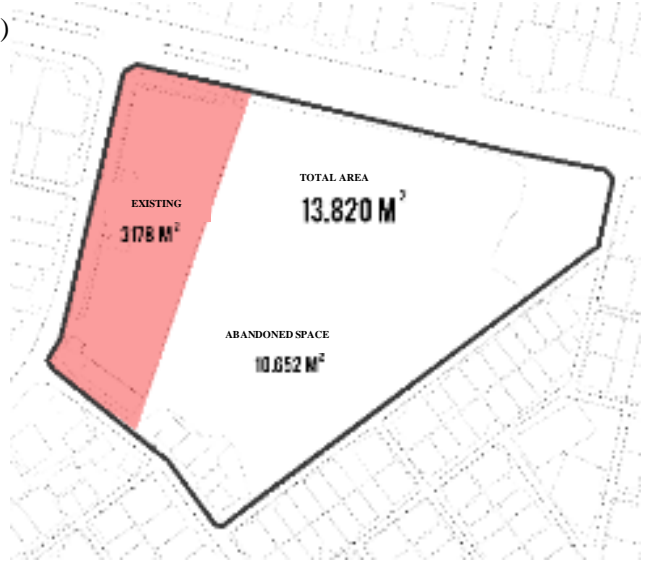

Fig. 4 a) Location of the Terminal; b) Terminal wide area 
Site zones are divided by the arrival loop modes. In accordance with the original concept that is park and ride, the main zones are divided into two zones, there are the main building and the parking zones. Divided into two separate parking zones back into bike parking and car parking.

\section{2) Parking Lot Analysis}

\section{Parking Needs}

Parking space requirement is the number of places needed to accommodate the vehicles requiring parking based on comfort and functionality of a land use. The formula used to calculate the parking space requirements are as follows:

\section{(1)}
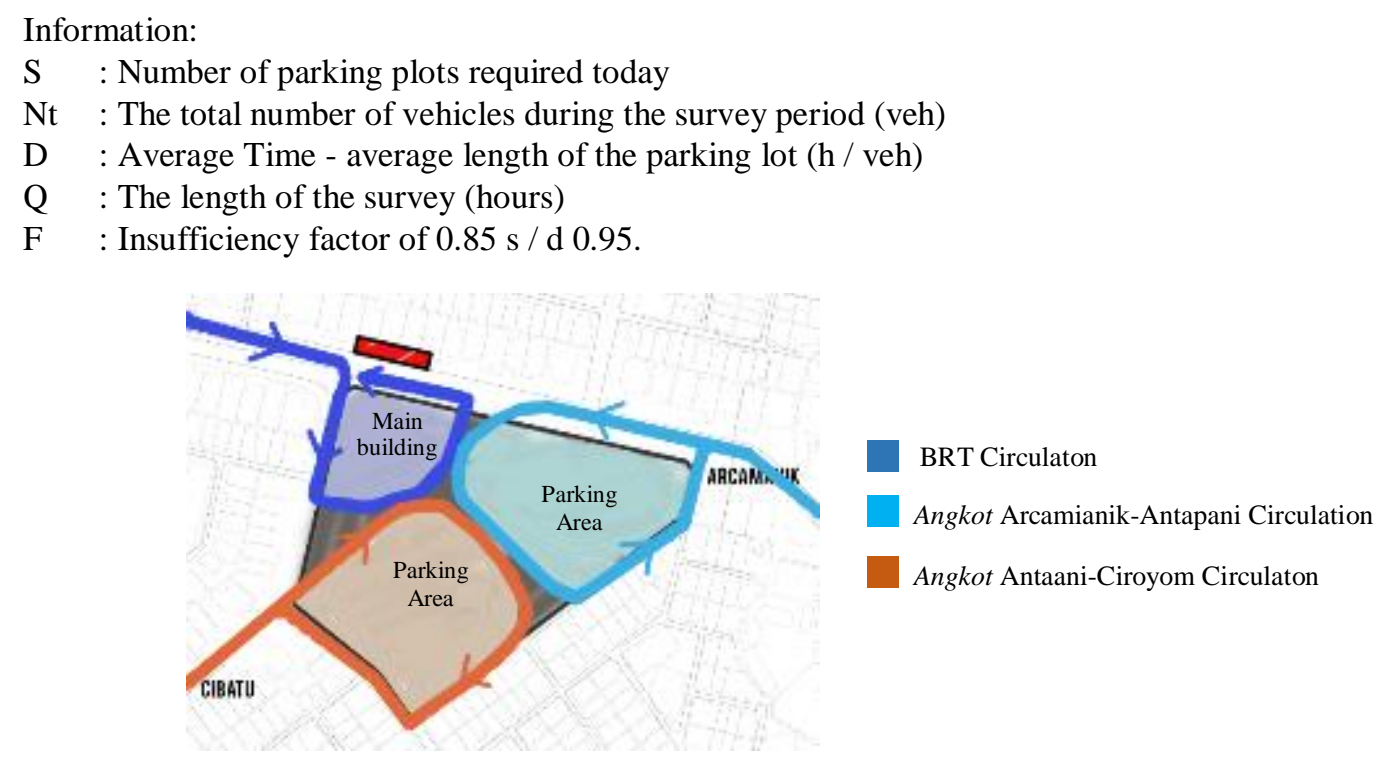

Fig. 5 Site zonation by mode's loop

Case on Antapani Terminal

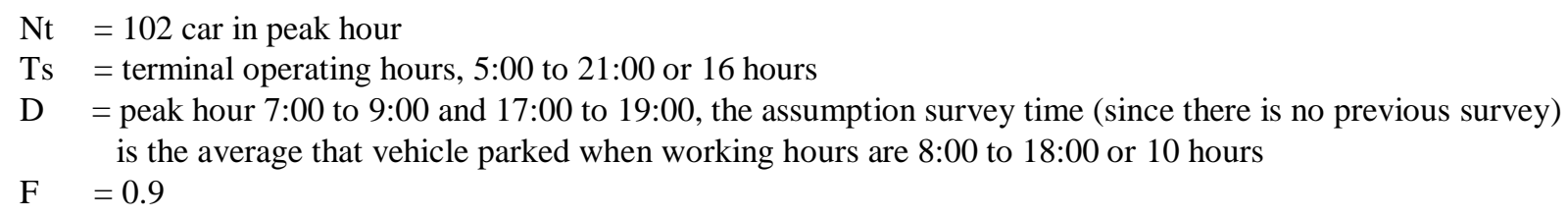

$$
\text { slots }
$$

\section{Parking Supply}

Parking Supply or the ability to provide parking is limit the size of the number of vehicles that can be accommodated during a certain period of time (during the time of the survey).

The formula used to calculate the provision (parking supply) is: 
Information:

Ps : The number of vehicles that can be parked (vehicle)

S : The total number of stall / official plot (plot)

Ts : Time survey (hours).

D : The average length of parking (hours / vehicle).

F : Insufficiency factor (0.85 to 0.90$)$.

Calculation on Antapani Terminal

So this terminal should have 102 slots of car parking to decrease the traffic density at peak hour in a day.

\subsubsection{Main Building Exploration}

Zonation in the main building divided by function in the terminal such as main functions, support functions and service area. Those will be grouped into three zones: private zone, semi-private zone and public zone. Private zone

a)

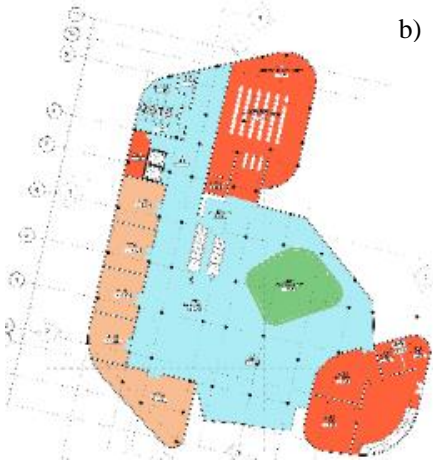

b)

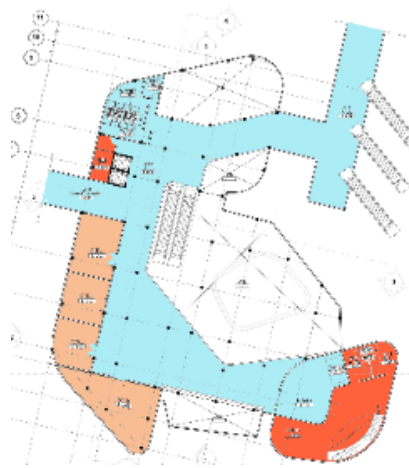

c)

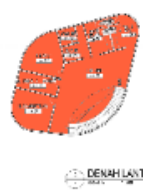

Private Zone

Semi Private Zone

Public Zone

Fig. 6 a) 1st floor zonation; b) 2nd floor zonation; 3) 3rd floor zonation

consists of a management office and the departure lounge. Departure lounge should be in the private zone because there are only people who have a ticket could enter the room. Therefore, semi-private zone is retail, and the rest is public zone.

The main building is a city node that would become a trademark in that region. So, the shape and mass of the building must be contrasted with its surroundings so people can get interest into the building at first and use the public transportation such as BRT, angkot, School Bus, or Monorail across the terminal.

\section{Design Concept}

The basic concept used is a response of the problems on the site with synthesized some values of the park and ride system. The Issues to be responsed is the result of a study by the author at the site, is:

a. The movement of people towards the downtown is very high.

b. High number of private vehicle ownership.

c. Public transportation stops at the terminal.

d. There is no public transportation that constantly approach the housing.

e. Within a radius of $2 \mathrm{~km}$ (to the nearest node) there is only one modes of public transportation. 
f. The terminal facilities are inadequate.

g. There is no waiting room for passengers.

h. Passengers too lazy to enter the terminal so that the activity of modes interchange was actually done arbitrarily.

i. There is no clear separation between people and vehiche circulation.

Based on the problems that has been found at the site, the basic concepts of planning and designing the terminal system based on park and ride system, is:

a. The building is the node, meeting point, and a magnet for people movement fro their house to the city. So the form of it would be like a scluptural terminal. It responses to the problem of the "lazy passengers" into the terminal. Terminal form which is contrasts with its surrounding, can attract people to go inside the terminal.

b. Bear the people movement with park and ride system. According to The Study of Bandung Transport, in 2013, 7.2\% of vehicles in Bandung out in the morning peak hour. From manual calculations, the number of vehicles passing through Jl. Terusan Jakarta is about 1140 units in every day. Through the calculation of the amount of parking supply, from the site conditions, the terminal is able to bear $33 \%$ of the traffic density with priority time on the morning peak hour (7:00 to 9:00). So, the park and ride system is able to reduce the density and minimize the congestion which caused by too many vehicles comes out at the same hour.

c. Clear separation of circulation between vehicles and people. The different circulation in and out people and vehicle affect the smooth circulation that will affect the travel time.

d. The main building consists of two main mass, and the intermediary mass that is open and light.

\section{1. Site Concept and Outer Space}

a)

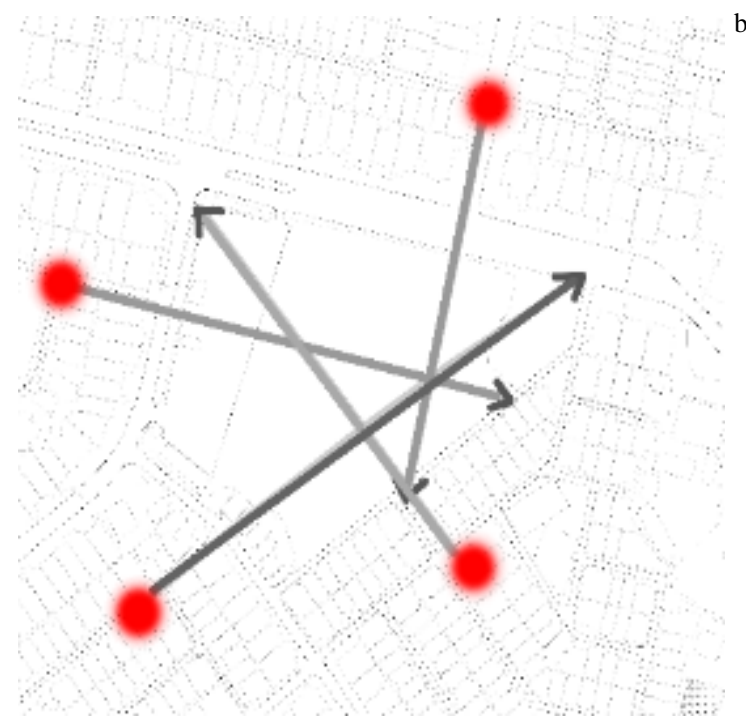

b)

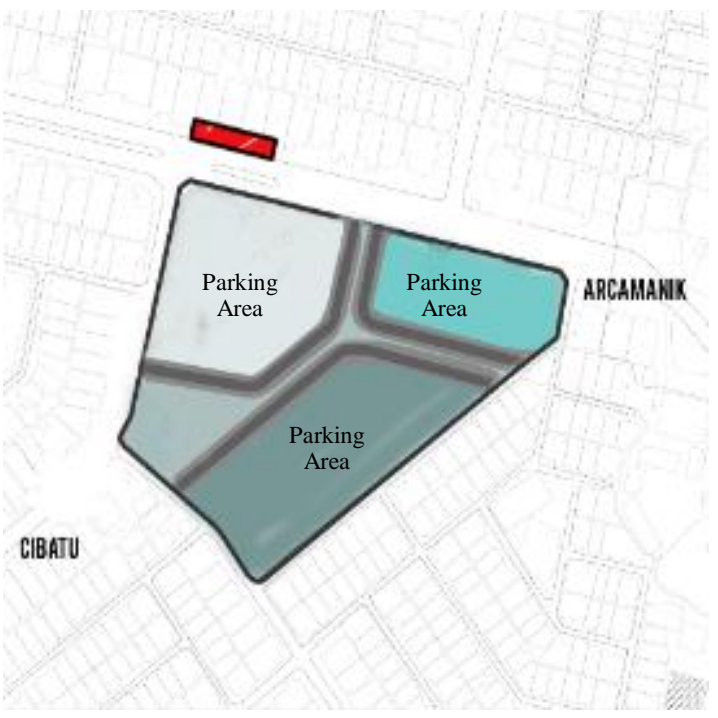

Fig. 7 a) Axis of people's arrival; b) Site Base Zone 
Site is formed by the axis of visitor's arrival and by the loop of the movement of public transportation that comes or goes from the terminal. Then, to design a terminal with park and ride system, site zonation is divided into a main building and parking are. Parking zone, then also divided into car parking and motorcycles and bicycle parking. Despite all these zoning is a circulation for all vehichels such as BRT, school buses, angkot, and private vehicles. The circulation of those vehicles is adapted by it comes and goes (to the terminal) direction.

However, the terminal is the last node for the BRT, angkot, and school buses, so it needs an interchange zone where people can move from one mode to another without interrupt each circulation both people and vehicles. This interchange zone is placed in the middle of all the circulation of vehicles, and it applied in the form of intermodal connectors.

Based on previous calculations, the capacity of the car parking at the terminal is 102 slots, but the terminal can supplied over the capacity, 109 slots for car parking. So as for motorcycle parking, the terminal supplied up to 270 slots and 117 for bicycle parking slot.

a)

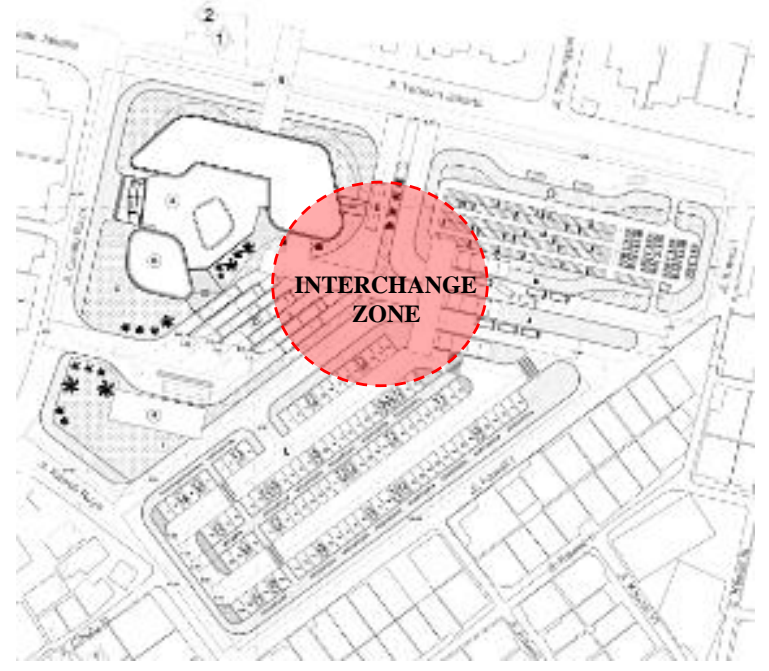

b)

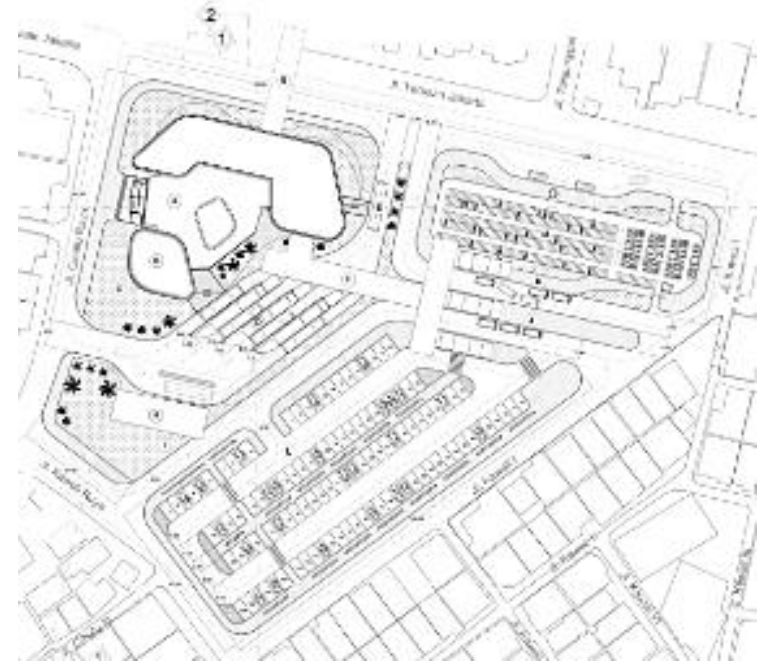

Fig. 8 a) Interchange zone; b) Blockplan

\section{2. Main Building Concept and Material Exploration}

As we all known that the main building is the city node that eventually would become a trademark and encourage people to go the terminal and use the public transportation, the shape and mass of the building is made into a grand massing. Thus hence, the mass is adjusted by the direction of the arrival of visitors. Also for zonation in the building. The application of the hole on the roof of the hall is used to eliminate the massive impression on the building, as well as using full window from top to bottom. One plant is actually added to the building to give the impression of open spaces although in a closed room.
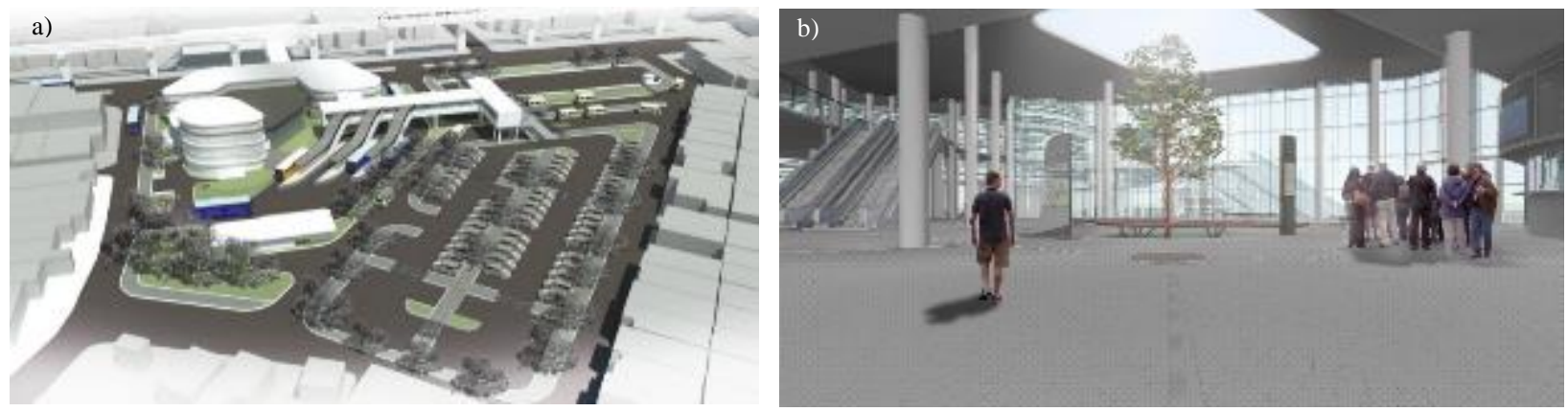

Fig. 9 a) Building mass; b) Hall interior 
Beside that, the facade of the building was made with the concept of contrast, so it looks futuristic with the metaphor of speed light as a symbol of a vehicle, which is this terminal is the transportation building that has priority to mode movement as fast as possible. Furthermore, it was a characteristic of the transportation itself, that is speed.

a) This facade is made by using hollow steel and coated with white ACP. White color implements the concept of futuristic and contrast with it surroundings. Different sizes of the fins are made for the dynamic looks. Behind these fins are clear glass, but at the top is perforated so air can flow into the building.Conclussions
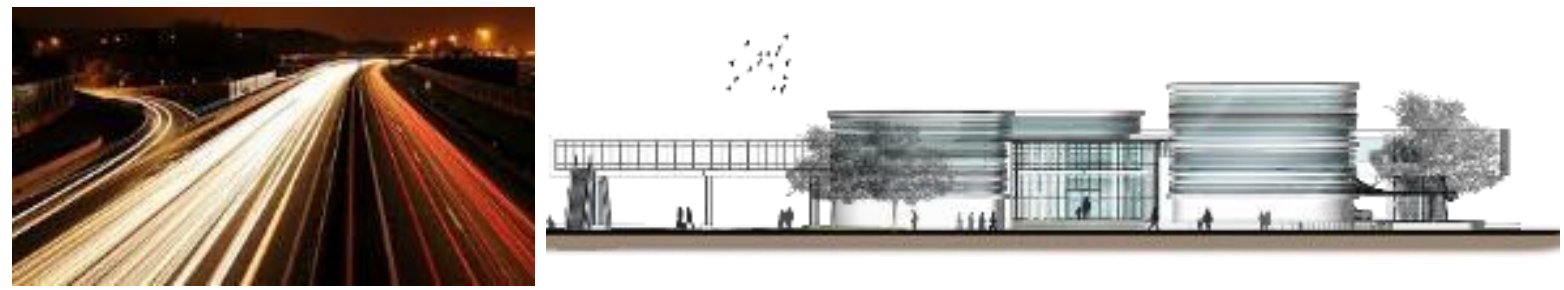

Fig. 11 a) Transformation of speed tight; b) Building facade

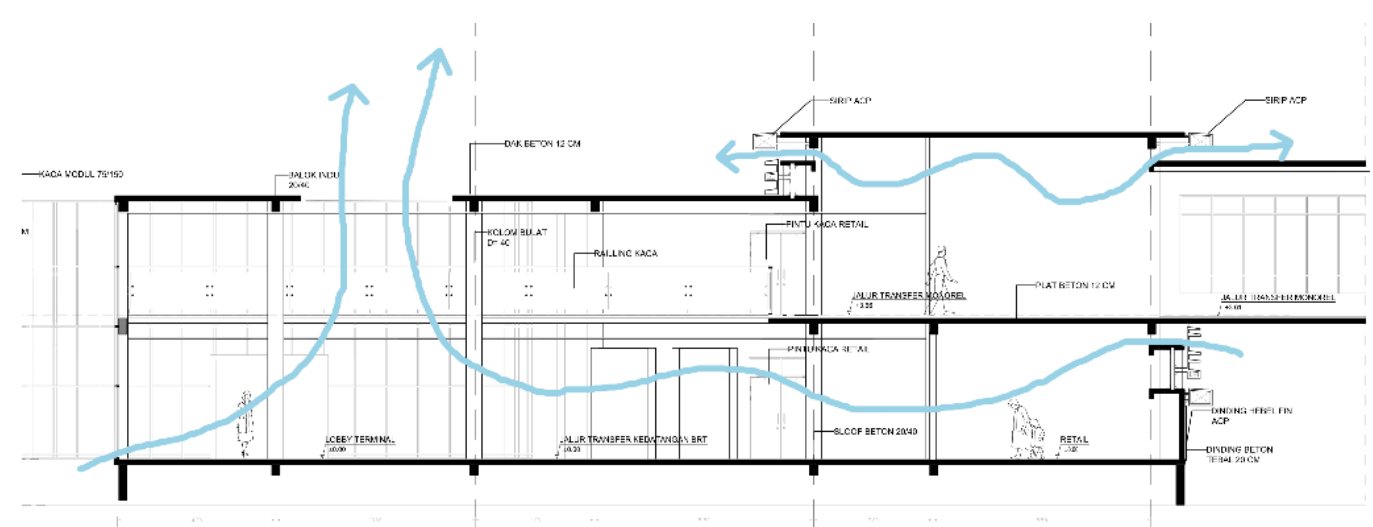

Fig. 10 Air flows by facade and roof hole

The main concept of this terminal is to encourage people to use public transportation with the concept of park and ride, where people whose their homes are not accessible by public transportation can use their personal vehicle just till the terminal, then park and continue their journey by public transport such as BRT, angkot, school buses or monorail. The number of parking slots is calculated based on the survey and count by the parking needs. In order to invite people to the terminal, the building was made in contrast theme into the futuristic concept. So that besides being a node, this terminal is also becoming a trademark for the region.

\section{References}

KEPMENHUB No. 31 Th. 1995. Terminal Transportasi Jalan (1995). 
-This page intentionally left blank-

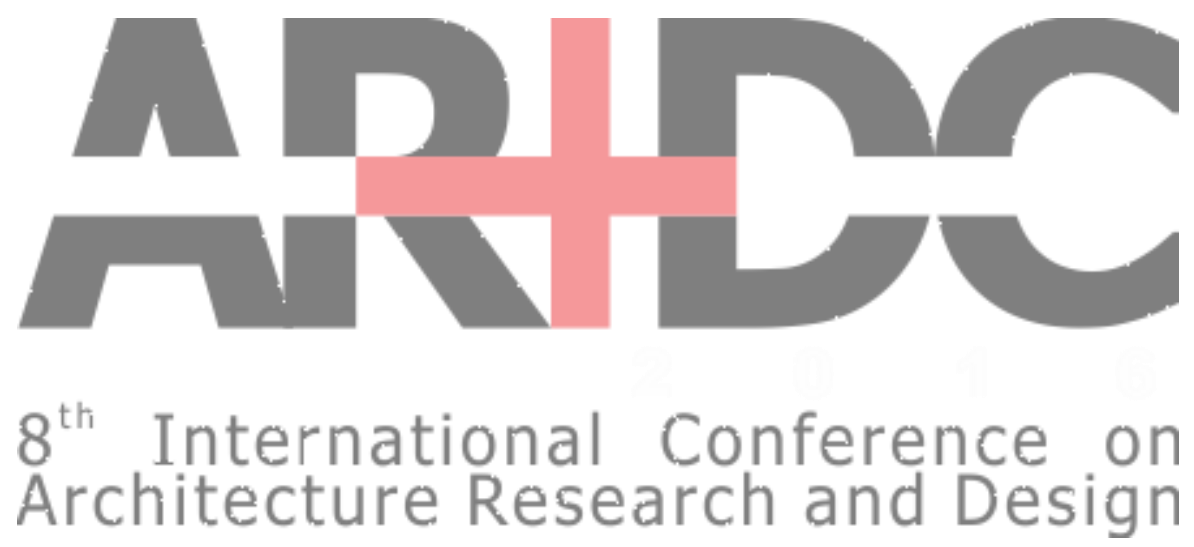

